\section{HSE}

Historia Social y de la Educación

Social and Education History
Hipatia Press

www.hipatiapress.com

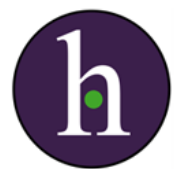

Instructions for authors, subscriptions and further details:

http://hse.hipatiapress.com

\title{
Umberto Tommasini, el Herrero Anarquista. Memorias de un Hombre de Acción
}

Josep Marcos ${ }^{1}$

1) Universitat Pompeu Fabra, España

Date of publication: June $23^{\text {rd }}, 2015$

Edition period: Edition period: June 2015-October 2015

To cite this article: Marcos, J. (2015). Umberto Tommasini, el Herrero anarquista. Memorias de un hombre de acción [Review of the book]. Social and Education History, 4(2), 214-216.

doi: $10.17583 /$ hse. 2015.1581

To link this article: http://doi.org/10.17583/hse.2015.1581

PLEASE SCROLL DOWN FOR ARTICLE

The terms and conditions of use are related to the Open Journal System and to Creative Commons Attribution License (CC-BY). 
HSE - Social and Education History Vol. 4 No. 1 Febraury 2015 pp. 214-216

\section{Reviews (II)}

Tommasini, Umberto. (2014). Umberto Tommasini, el Herrero Anarquista. Memorias de un Hombre de Acción. Madrid: Fundación Anselmo Lorenzo. ISBN 9788486864880.

T an tenido que pasar 30 años para que se publique en castellano el - relato biográfico del activista libertario italiano Umberto Commasini (1896-1980), testigo en primera persona de algunos de los grandes acontecimientos de la historia de Europa del siglo XX, como las dos guerras mundiales, la ascensión del fascismo, la guerra civil española, la ocupación yugoslava de Trieste y las convulsiones del 1968. Editado en el año 1984 por el historiador italiano Claudio Venza, se hace extraña la demora de su publicación en nuestro país (en el 2011 aparece una primera edición en catalán), pues estamos ante un testimonio muy importante de la guerra civil española, que aporta datos sobre la participación extranjera más allá de lo que fueron las brigadas internacionales y que enmarca el conflicto en una dimensión internacional. La versión en castellano viene introducida por una entrevista realizada por Venza en el 2011 al escritor Claudio Magris en la que se destaca la importancia del relato. El libro es la transcripción de una larga entrevista en la que Tommasini, herrero de profesión y luchador incansable por una sociedad más justa y solidaria, explica su vida. Nacido en Trieste en 1896, ciudad que pertenecía en aquel momento al imperio austro-húngaro, inicia su activismo de muy joven de la mano de su padre, militante socialista, participando en una huelga general en 1909 convocada como protesta por el asesinato del pedagogo catalán Francesc Ferrer y Guardia. Al estallar la I Guerra Mundial pasará la familia 
a territorio italiano, siendo llamado a filas para luchar en el duro frente alpino, experiencia que marcará profundamente su carácter. La crisis social y económica de la postguerra italiana y el ascenso del fascismo radicaliza la conflictividad social, es cuando Tommasini abandona progresivamente el socialismo por el anarquismo. Aquí la narración muestra la inadaptación social en la postguerra de los que estuvieron en las trincheras "generaciones del frente" que a menudo adoptan la violencia como expresión política, provocando una ruptura con la generación anterior, que en el libro se percibe en la relación con su padre que no aprueba la deriva violenta del país y en particular la de su hijo. La participación en un atentado contra Mussolini lo llevará a ser detenido y confinado en las islas entre 1926-1932. Puesto en libertad se exiliará a Paris donde continuará su activismo, marchando a España al estallido de la guerra civil y participando como miliciano libertario en la columna Ascaso en el frente de Aragón, otro episodio de su vida que le marcará profundamente. La guerra se presenta para una parte de la izquierda internacional como la posibilidad de derrotar por primera vez al fascismo en Europa. La esperanza y entusiasmo que deposita en la revolución española pronto se verá frustrada por la actitud antirrevolucionaria de los estalinistas, siendo detenido y encarcelado por estos por su militancia anarquista. Marchará de España por el devenir de los acontecimientos que han llevado a la hegemonía comunista en el bando republicana, gracias al apoyo de la URSS, que reprime sus opositores políticos, siendo asesinado su compañero Berneri por los estalinistas en Barcelona en los enfrentamientos de mayo de 1937. Tommasini vuelve a Italia al inicio de la II guerra mundial, negándose a luchar junto los partisanos por el predominio comunista en estos. Acabada la guerra continuará su militancia anarquista, siendo muy crítico al bloque soviético y al Partido comunista italiano (PCI) especialmente en la persona de Vidali, que también estuvo en España durante la guerra civil luchando en las brigadas internacionales y que Tommasini acusa de su implicación en los crímenes del comunista italiano Luigi Calligaris, crítico a la URSS, así como el del líder del POUM Andreu Nin. También testigo de la ocupación de Trieste por los partisanos de Tito, que priorizan como estrategia el nacionalismo paneslavista al internacionalismo proletario para hacerse con el control del territorio. La última parte del libro relata su infatigable 
activismo libertario durante la postguerra, con grandes dificultades ante el papel hegemónico del PCI en la izquierda. Asimismo observa atónito, la permisividad de la democracia italiana de la postguerra ante el neofascismo. Durante los años que rodean el convulso 1968, ve como el anarquismo resurge, así como se tensa de nuevo el clima social con una nueva espiral de violencia, en la que ya anciano defenderá con fuerza el local de su agrupación de una agresión violenta de los neofascistas.

Por otra parte el herrero anarquista, es un testimonio de la lucha por el empoderamiento cultural de las clases populares como estrategia revolucionaria. Ya en sus primeros pasos junto a su padre vemos a Tommasini participando en la creación de una biblioteca popular en Vivaro. Así como la ferviente necesidad de editar prensa escrita, como órgano propagador de ideas. Un libro que es una ventana al siglo $\mathrm{XX}$, y que Claudio Magris define en la introducción como un clásico tanto como documento histórico, como por su dimensión humana.

Josep Marcos

Universitat Pompeu Fabra josepmarcos4@gmail.com 